Revue

Revue de l'histoire des religions

de Ihistoire des religions

Fabienne JAGOU (éd.), The Hybridity of Buddhism:

Contemporary Encounters between Tibetan and Chinese

Traditions in Taiwan and the Mainland

Paris, École française d'Extrême-Orient («Études Thématiques », 29),

2018

Jonathan Samuels

\title{
CpenEdition
}

Journals

Electronic version

URL: https://journals.openedition.org/rhr/10812

DOI: $10.4000 /$ rhr. 10812

ISSN: 2105-2573

Publisher

Armand Colin

Printed version

Date of publication: 1 September 2020

Number of pages: $497-500$

ISBN: 978-2-200-93327-2

ISSN: 0035-1423

Electronic reference

Jonathan Samuels, "Fabienne Jagou (éd.), The Hybridity of Buddhism: Contemporary Encounters between Tibetan and Chinese Traditions in Taiwan and the Mainland", Revue de I'histoire des religions [Online], 3। 2020, Online since 01 January 2021, connection on 06 January 2023. URL: http:// journals.openedition.org/rhr/10812 ; DOI: https://doi.org/10.4000/rhr.10812

This text was automatically generated on 6 January 2023 .

All rights reserved 


\section{Fabienne JAGOU (éd.), The Hybridity of Buddhism: Contemporary Encounters between Tibetan and Chinese Traditions in Taiwan and the Mainland}

Paris, École française d'Extrême-Orient («Études Thématiques », 29), 2018

Jonathan Samuels

\section{REFERENCES}

Fabienne JAGou (éd.), The Hybridity of Buddhism: Contemporary Encounters between Tibetan and Chinese Traditions in Taiwan and the Mainland, Paris, École française d'Extrême-Orient ("Études Thématiques », 29), 2018, 236 p., 28 cm, 40 €, ISBN 978-2-85539-149-6.

This volume comprises eight articles (seven in English, one in French), plus the editor's introduction, and concerns itself, primarily, with issues related to the Taiwanese reception of Tibetan Buddhism. Tibetan forms of Buddhism are of a variety distinct from those usually described as "Chinese" (or in this case, "traditional"): hybridity is the concept chosen here to represent the expressions of Buddhism that result from the meeting of the two. Tibetan Buddhism experienced a major growth in popularity in Taiwan (the most up-to-date figures speak of 600,000 devotees from a total population of around 23 million) following a series of visits (beginning in 1997) made by the Dalai Lama. Thus, events of recent decades greatly inform the volume's perspective on hybridity: it is treated as a relatively modern phenomenon, understood within a contemporary setting. The broadest historical framework within which the engagement between the two religious traditions is conceived is that defined by state: it began no earlier than 1949, the year that Chinese Kuomintang forces (under Chiang Kai-shek) withdrew to Taiwan, having lost the civil war to Mao's Communists, and the 
two 'Republics of China' (the PRC and ROC) set about realising parallel visions of state on their respective mainland and island territories, and pursuing (with contrasting vigour and success) their rival claims to be China's legitimate rulers.

The editor's argument for using hybridity, as opposed to syncretism, as a way of characterising the results of the encounter between traditions is cogent. The volume considers different facets and dimensions of the hybridity: Tibetan Buddhism's influence is expressed most strikingly in the contributions about temple architecture (Frazer), spirit-possession (Huang), and esoteric revivalism (Bahir). The editor refers to "a new form of humanitarian Buddhism", meaning a Taiwanese, Tibetan-themed variety of Buddhism, notable for its social-orientation and charitable aspect. But this is not a unified movement or school. The deeper picture that emerges is that of a series of relationships with symbiotic characteristics, although on neither side are there coherent "organisms" (states, societies, or religions) involved. Instead, we see various individuals and groups, on both Taiwanese and Tibetan sides, who are beneficiaries of different arrangements. Charismatic Tibetan Buddhist teachers (or sometimes their native followers, such as the Taiwanese nun, Elder Gongga) appeal to a devotionally inclined populace, who are materially wealthy, but time impoverished. Generous financial donations, directed towards these teachers, are channelled into their own monastic institutions or projects in India, Nepal, or Tibet. For the Taiwanese faithful, Tibetan Buddhism has both exotic freshness and ancient authenticity: perceived features that can be evoked or manipulated to serve multifarious contrasting (and sometimes opposing) functions and purposes. Thus, Tibetan Buddhist traditions are used as legitimisation devices, they may facilitate the forging of new identities or the "rediscovery" of old ones, and they can provide vantage points from which a critical gaze can be cast on the institutions in established Chinese Buddhism. Much of this volume's value lies in the light it sheds on how creatively tradition is being used.

There is, however, some unevenness within the contributions, as with aspects of the editorship. The mainland of the subtitle is also represented minimally. Only two chapters (by Bianchi and Turek) deal with PRC territory. Adding to the growing literature relating to the Tibetan Buddhist centre of Larung gar in Sertar (Sichuan), the first illustrates how Tibetans practicing their own Buddhist traditions simultaneously reach out, culturally and technologically, in ways that appeal to numerous Chinese urbanites. The second chapter concentrates specifically on Tibetan traditions for Tibetans. There is no discernible hybridity, and aside from in a brief addendum, little reference is made to any sort of Chinese-Tibetan interface.

Overtly, politics does not feature heavily in this volume. This might attract some readers but creates problems for those unfamiliar with the terrain. The volume never fully acknowledges the existence of three distinct community identities (Tibetan, Taiwanese, and mainland Chinese) nor the pronounced differences separating them. It repeatedly relies on the "traditional" vocabulary of the "transnational", although the divisions here are neither characterizable as wholly national (only the PRC is universally recognised as a nation-state), nor ethnic (Taiwan and the PRC both have Han-majority populations). Critically, these identities are historically linked with three rival claims to sovereignty over Tibet, something that, in the Taiwanese case, the workings of the shadowy Mongolian and Tibetan Affairs Committee (MTAC) remind us. These claims and associated questions about political loyalties have coloured relations between members of the groups, with constant concerns about hidden agendas and the political 
implications behind actions and contacts of a "religious" nature. Readers unapprised of this information are at a disadvantage, and are unlikely to fully appreciate the significance of the more recent forms of hybridity, manifesting in the formation of new religious networks, communities, and channels of discourse, the most striking feature of which is their ability to transcend the rigidity of identities defined by nation and ethnicity.

5 The historical framework defined by state appears logical and helps avoid embroilment in certain complex issues. Nevertheless, in terms of the engagement between Tibetan and Chinese forms of Buddhism, 1949 marks an artificial boundary. The relationship has centuries of history. Campergue's contribution to the volume, which is based on answers to a questionnaire that prove surprisingly informative regarding the attitudes of Taiwanese devotees, includes a photograph of a banner hanging from the side of a wall in Taiwan. It announces, "Tibetan Buddhism is definitely not Buddhism, the lamas are not Buddhist monks or nuns". Unfortunately, neither in Campergue's article nor anywhere else in the volume is any mention made of the historical tensions underlying such eruptions. Thus, again, the reader is denied a vital part of the picture and could be forgiven for assuming that the relationship is purely a modern one, and that Tibetan Buddhism's arrival in Taiwan conforms to a pattern witnessed in other industrialised societies, following visits from the Dalai Lama. The reader's understanding of the volume's contents could only have been enhanced if some reference or clarification of such matters, however brief, had been included.

Only two contributors are Taiwanese; something that might engender unease, given that the volume arises from a collaborative project organised by a Taiwanese foundation. Rather than deriving from an unconscious editorial bias, this representational imbalance relates, one suspects, to the issue of academic standards. Huang's piece about spirit-possession is engrossing material (the idea of a medium in conflict with his spirit is something of a gift), but Hsiao's chapter, which reads more like a homage to a Taiwanese personage seems more reflective of the tradition. A major gulf in understanding regarding what constitutes an academic piece of work separates Western and Taiwanese/Chinese traditions. Increased collaboration alone is incapable of breaching the gulf, not least because the topic is one that project participants find it almost impossible to broach.

7 Neither the imbalance itself nor a lack of reference to it can be counted as deficiencies in this volume. But it can be criticised for its disappointing treatment of Tibetan Buddhism. Characterisation of the Tibetan Buddhist schools is clichéd. The differences between them are presented as clear-cut, according to orientation (the intellectual versus the contemplative) or even reduced to the colour of their headgear (the "red hat" versus the "yellow hat"); simplifications with decidedly sectarian undertones. This kind of reductive representation (or crude pigeon-holing) serves religion's commoditisation in both Taiwanese and Western settings, where new forms of Tibetan Buddhism have been created to suit communities of predominantly lay adherents, with the right to exercise something akin to consumerist choice. The representation of Tibetan Buddhist schools here is one that combines pre-1949 Chinese stereotypes with modern Western ones. Unfortunately, this variety of hybridity is one of which the volume displays no awareness. This criticism notwithstanding, the volume is still a worthwhile read. It would have benefitted from greater contextualisation, but the topic 
it deals with is genuinely interesting and at times fascinating. The contributions, while not consistently insightful, are generally informative.

\section{AUTHORS}

JONATHAN SAMUELS

Wolfson College, University of Oxford. 